Article

\title{
Enriched Co-Treatment of Pharmaceutical and Acidic Metal-Containing Wastewater with Nano Zero-Valent Iron
}

\author{
Thobeka Pearl Makhathini ${ }^{1,2, * \mathbb{C}}$, Jean Mulopo ${ }^{1}$ and Babatunde Femi Bakare ${ }^{2}$ \\ 1 School of Chemical and Metallurgical Engineering, University of the Witwatersrand, P/Bag 3, Wits, \\ Johannesburg 2050, South Africa; jean.mulopo2@wits.ac.za \\ 2 Department of Chemical Engineering, Mangosuthu University of Technology, 511 Griffiths Mxenge, \\ Umlazi 4031, South Africa; bfemi@mut.ac.za \\ * Correspondence: thobeka@mut.ac.za; Tel.: +2731-907-7141
}

Citation: Makhathini, T.P.; Mulopo, J.; Bakare, B.F. Enriched Co-Treatment of Pharmaceutical and Acidic

Metal-Containing Wastewater with Nano Zero-Valent Iron. Minerals 2021, 11, 220. https://doi.org/10.3390/ $\min 11020220$

Academic Editor:

Vhahangwele Masindi

Received: 8 January 2021

Accepted: 15 February 2021

Published: 20 February 2021

Publisher's Note: MDPI stays neutral with regard to jurisdictional claims in published maps and institutional affiliations.

Copyright: (c) 2021 by the authors. Licensee MDPI, Basel, Switzerland. This article is an open access article distributed under the terms and conditions of the Creative Commons Attribution (CC BY) license (https:// creativecommons.org/licenses/by/ $4.0 /)$.

\begin{abstract}
Among traditional hazardous waste sources, pharmaceutical-containing wastewater and acidic mine drainage need treatment to preserve the expected water supply quality. A nano zerovalent iron (nZVI)-enriched treatment of these two streams is evaluated for simultaneous removal of various heavy metal ions, organic pollutants, sulfates, the efficiency of the treatment system, and separation of reaction products in the fluidized-bed reactor. The reactor packed with silica sand was inoculated with sludge from an anaerobic digester, then 1-3 g/L of nZVI slurry added to cotreat a hospital feed and acid mine wastewater at 5:2 v/v. The biotreatment process is monitored through an oxidation-reduction potential (Eh) for 90 days. The removal pathway for the nZVI used co-precipitation, sorption, and reduction. The removal load for $\mathrm{Zn}$ and Mn was approximately 198 $\mathrm{mg} \mathrm{Zn/g} \mathrm{Fe} \mathrm{and} 207 \mathrm{mg} \mathrm{Mn/g} \mathrm{Fe,} \mathrm{correspondingly;} \mathrm{achieving} \mathrm{sulfate} \mathrm{(removal} \mathrm{efficiency} \mathrm{of} 94 \%$ and organic matter i.e., chemical oxygen demand (COD), biological oxygen demand (BOD), dissolved organic carbon (DOC), total dissolved nitrogen (TDN) reduced significantly, but ibuprofen and naproxen achieved $31 \%$ and $27 \%$ removal, respectively. This enriched cotreatment system exhibited a high reducing condition in the reactor, as confirmed by Eh; hence, the nZVI was dosed only a few times in biotreatment duration, demonstrating a cost-effective system.
\end{abstract}

Keywords: zero-valent iron; cotreatment; acidic mine drainage; fluidized-bed reactor

\section{Introduction}

Acidic mine water resulting from the open mine tailings often contains sulfates and a complex mixture of heavy metal ions. These mine tailings are characterized to have a high concentration of sulfide containing minerals, such as pyrite $\left(\mathrm{FeS}_{2}\right)$. As a result, pyrite's bio-hydro-geochemical weathering with other sulfide containing minerals in oxidizing conditions produces acid mine drainage [1]. According to Masindi and Muedi [2], the formation of acid mine drainage (AMD) may be represented as:

$$
2 \mathrm{FeS}_{2}+\mathrm{O}_{2}+2 \mathrm{H}_{2} \mathrm{O} \rightarrow 2 \mathrm{Fe}^{2+}+4 \mathrm{SO}_{4}^{2-}+\mathrm{H}^{+}
$$

Through sulfide oxidation to sulfate solubilizes the $\mathrm{Fe}^{2+}$ Equation (1), then oxidized to $\mathrm{Fe}^{3+}$ Equation (2):

$$
4 \mathrm{Fe}^{2+}+\mathrm{O}_{2}+4 \mathrm{H}^{+} \rightarrow 4 \mathrm{Fe}^{3+}+2 \mathrm{H}_{2} \mathrm{O}
$$

Microorganisms, such as iron-oxidizing bacteria, can be catalyzed by microorganisms that draw energy from oxidation reaction. Then $\mathrm{Fe}^{3+}$ produced may also oxidize $\mathrm{FeS}_{2}$ and also be reduced into $\mathrm{Fe}^{2+}$ Equation (3):

$$
\mathrm{FeS}+14 \mathrm{Fe}^{3+}+5 \mathrm{H}_{2} \mathrm{O} \rightarrow 15 \mathrm{Fe}^{2+}+2 \mathrm{SO}_{4}^{2-}+16 \mathrm{H}^{+}
$$


Generally, acid mine drainage contains metal concentrations that pose a risk to the environment and is strongly acidic. In South Africa, the mining industry is one of its economy's driving industries [3]; on the other hand, this industry's impact on the environment through the generation of acid mine drainage (AMD) is a call for concern. More so, a crisis in abandoned mining sites is the less attention given to remediate AMD, resulting in the significant environmental problem in South Africa (SA) and globally. AMD remediation for heavy metal removal includes adsorption, biosorption, ion exchange, filtration, precipitation, and stabilization [2].

AMD is not the only challenging water pollutant in SA; pharmaceutical compounds originating from hospital wastewater (HWW) are frequently found in natural water bodies and increasingly become a persistent pollutant requiring attention. Hospital wastewater is among the commonly found effluent in urban water streams, mainly pharmaceutical, toxic chemicals, and pathogens as dominant pollutants [4,5]. Regrettably, all these pollutants are typically pumped to the municipal wastewater treatment plants (WTTPs), regardless of the call to hold the wastewater on-site for treatment before pumping to WTTPs [6]. The on-site wastewater retention and prior treatment of HWW may help treat most hazardous pollutants before discharge to the natural environment. The pharmaceutical compounds' chemical and physical properties resulting in their polarity in nature hence resistant to degradation processes in WTTPs. Hence an urge to find new treatment strategies that are more environmentally friendly and minimize acute health threats from HWW. Noticeably, the regulation on pharmaceuticals disposal or their treatment is not as stringent in emerging economies, including SA, in comparison to developed countries. Hence the current design of wastewater treatment facilities does not bear the capacity to remove pollutants like pharmaceuticals. To date, more methodologies have been investigated to support the integration of growing pharmaceutical pollutants into South Africa's water quality legislation.

A plan to employ a cotreatment strategy for simultaneous remediation of AMD and HWW is proposed after briefly providing the background of these two hazardous pollutants. This proposal is an extension of published studies that cotreated AMD and municipal wastewater, achieving success in reducing metal concentration and sulfates [7-9]. In these studies, municipal wastewater MWW offered carbon substrate bacterial oxidation to reduce the metals, while pathogens are removed from it as well [10]. The hospital wastewater is much richer in nutrients and organic carbon, making it slightly superior to municipal wastewater, hence promises higher alkalinity production. In the studies by Strosnider et al. $[9,11,12]$, where MWW was cotreated with AMD, the organic matter from MWW was used to strip-off bacterial oxygen thud reduction in metal concentration and sulfate. As an alternative, an aerobic process is preferred to remove high strength organic matter. This cotreatment strategy's efficacy is better described in Makhathini et al. [13]; however, the heavy metals such as $\mathrm{Pb}, \mathrm{As}$, and $\mathrm{Mn}$ were not documented as they experienced a low removal rate in this system. As such, the cotreatment needs to be enhanced to assess its efficacy under the presence of nZVI, specifically to assess the heavy metals.

According to Dong et al. [14], the nZVI promises a beneficial influence on sulfatereducing bacteria's development and activity. As such, it is expected that the wastewater under hypoxic groundwater environment, the $\mathrm{Fe}^{0}$ will be oxidized to ferrous iron, thus increasing the $\mathrm{pH}$ value of the treatment system through the discharge of $\mathrm{OH}^{-}$ion [15]. Kumar et al. [16] assert that the alkaline conditions emanating from $\mathrm{Fe}^{0}$ oxidation are favorable for developing sulfate-reducing bacteria, and hydrogen and $\mathrm{Fe}^{2+}$ may act as energy sources $\mathrm{SO}_{4}{ }^{2-}$-reduction by sulfate-reducing bacteria. Moreover, $\mathrm{Fe}$ (II) has a beneficial effect in hydrogenase synthesis, which is intricate for the sulfate-reducing bacteria (SRB) metabolism process of electron transfer and mass transport [17]. Generally, the SRB systems are known to take a long time for treatment because of lacking the energy source; however, to increase the remediation efficacy, $\mathrm{Fe}^{0}$ introduction could assist in speeding up the SRB process [17]. Therefore, the SRBs' possibility to gain from interacting with nZVI 
for heavy metals' removal and stabilization of precipitates is to be tested in this treatment system.

Notably, the main reason for using fluidized bed reactors for this system rather than packed-bed or anaerobic fixed-bed bioreactors is their superiority in retaining the biomass and achieving large mass transfer with less pressure drop. While anaerobic fixedbed and packed-bed bioreactors have demonstrated good remediation performances for wastewater [18], yet they are likely susceptible to blockages and channeling, which lessen their efficacy [19]. Furthermore, Sahinkaya et al. [20] and Kaksonen et al. [21] agree that the fluidized bed reactor (FBR) recycling stream decreases concentrations in the feed, thus rendering these bioreactors most fitting for acid mine drainage. However, just like most treatment systems, the cotreatment of two wastewater streams has shortcomings for one effluent's transportation cost to the shared facility [22]. Generally, AMD is formed some distance away from the urban area where hospitals might be situated; perhaps pumping cost may equip them with the cotreatment system's savings. However, some authors have constructed a wetland to treat hospital wastewater [23], as such, with an abundance of literature on wetlands from the treatment of AMD [7,24-26], this gives hope that such cotreatment strategy may be possible to set up.

This work reports on the application of nZVI as an enhancing reagent in the cotreatment of AMD and HWW using fluidized-bed reactors for the removal of heavy metals and toxic pollutants. A $2000 \mathrm{~mL}$ FBR was fed with nZVI slurry and operated continuously at a flow rate of $1.5-3.0 \mathrm{~m}^{3} / \mathrm{h}$. The $\mathrm{nZVI}$ slurry was fed from the top of the column while the effluent's feed was from the bottom, hence the slurry's suspension. The main objective was to assess the treatment process's efficiency while treating the real stream of AMD with a high content of heavy metals and sulfates, together with a real stream of HWW with a high content of organic matter, including the pharmaceuticals. Furthermore, the study seeks to contribute to AMD remediation literature using cotreatment strategies, thus guiding future design.

\section{Materials and Methods}

\subsection{Materials and Initial Experiments}

nZVI supplied by Romachem (SA) with a specific surface area recorded as approximately $20 \mathrm{~m}^{2} / \mathrm{g}$. Initially, to prepare the nZVI slurry, $250 \mathrm{~g}$ of $\mathrm{nZVI}$ particles were mixed to $1000 \mathrm{~mL}$ of deionized water to check the slurry's consistency. After this, the preparation was done to fill a $5000 \mathrm{~mL}$ container at a final $w / w$ Fe to water ratio of 0.25 [27]. The $\mathrm{Fe}^{0}$ content in the slurry was measured to be $93 \%$, based on the amount of hydrogen gas emitted when iron nanoparticles react at a volumetric volume of $60 \%$ with the addition of sulfuric acid [28]. There was no activation procedure investigated to enhance the reactivity of surface nZVI particles before application. The slurry was then continuously stirred at $\pm 20{ }^{\circ} \mathrm{C}$ while monitoring electrode potential $\left(\mathrm{E}_{\mathrm{h}}\right)$ and $\mathrm{pH}$ using oxidation-reduction potential and $\mathrm{pH}$ electrodes. Later after the $\mathrm{E}_{\mathrm{h}}$ of the slurry was observed to have stabilized using the oxidation-reduction. Sampling was done at $60 \mathrm{~min}$ intervals, where at least $20 \mathrm{~mL}$ samples were withdrawn then filtered using 0.2-micrometer membrane filters.

The AMD samples were collected from an abandoned coal mine in Mpumalanga, South Africa. To investigate the nZVI concentration effect, batch experiments were set up in five $650 \mathrm{~mL}$ glass bottles sealed with plastic caps with a 5:2 v/v of HWW to AMD mixture (pollutant characteristics listed in Table 1) and an nZVI slurry prepared as the different mass dosage of nZVI between 0.5 and $12 \mathrm{~g} / \mathrm{L}$. Each mixture in a batch reactor of AMD and HWW was dosed with a different slurry concentration. An additional two bottles without nZVI were also set up in parallel to the five bottles as control experiments. The batch reactors were agitated at room temperature on a shaker at 280-310 rpm. A selected number of heavy metals like $\mathrm{Pb}, \mathrm{Zn}$, and $\mathrm{Mn}$, which were not previously removed, were of interest here; hence they were measured using Inductively Coupled Plasma-Optical Emission Spectrometry ICP-OES (Varian 720-ES). After optimizing the slurry concentration, the slurry concentration was kept between 0.5 and $2.5 \mathrm{~g} / \mathrm{L}$. The fresh slurry was only made 
twice in the biotreatment duration since there was less demand for it (more details are given in the discussion session).

Table 1. Characterization of the acidic mine water samples.

\begin{tabular}{ccc}
\hline Parameters & Acidic Mine Water & Hospital Wastewater \\
\hline $\mathrm{pH}$ & $\pm 2.1-3.8$ & $\pm 6.2-7.9$ \\
$\mathrm{COD}(\mathrm{mg} / \mathrm{L})$ & \pm 98 & $\pm 156-1234$ \\
$\mathrm{PO}_{4}{ }^{3-}$ & $\pm 11-31$ & $\pm 9.8-14$ \\
$\mathrm{NH}_{4}{ }^{+}$ & $\pm 34-87$ & $\pm 34-87$ \\
Total nitrogen $(\mathrm{mg} / \mathrm{L})$ & $\pm 21-123$ & $\pm 45-223$ \\
Aluminum $(\mathrm{mg} / \mathrm{L})$ & \pm 275 & $<2$ \\
Potassium & \pm 34 & $<1$ \\
Iron $(\mathrm{mg} / \mathrm{L})$ & \pm 5329 & - \\
Sodium $(\mathrm{mg} / \mathrm{L})$ & $<0.05$ & $<6$ \\
Calcium $(\mathrm{mg} / \mathrm{L})$ & \pm 210 & \pm 56 \\
Copper $(\mathrm{mg} / \mathrm{L})$ & \pm 112 & \pm 23 \\
Zinc $(\mathrm{mg} / \mathrm{L})$ & \pm 145 & - \\
Manganese $(\mathrm{mg} / \mathrm{L})$ & \pm 113 & \pm 29 \\
Magnesium $(\mathrm{mg} / \mathrm{L})$ & \pm 243 & \pm 134 \\
Sulfate $(\mathrm{mg} / \mathrm{L})$ & \pm 4900 & $\pm 11-52$ \\
Turbidity $(\mathrm{NTU})$ & $\pm 46-55$ & $>413$ \\
Conductivity $(\mu \mathrm{S} / \mathrm{cm})$ & $>82$ & $2.39 \pm 0.75$ \\
Naproxen $(\mu \mathrm{g} / \mathrm{L})$ & - & $8.72 \pm 0.98$ \\
Ibuprofen $(\mu \mathrm{g} / \mathrm{L})$ & - &
\end{tabular}

(-) undetectable.

\subsection{Fluidized-Bed Reactors}

An existing laboratory-scale fluidized bioreactor was converted to an nZVI reactor (Figure 1). The reactor used an effective bed volume of $1400 \mathrm{~mL}$, which was packed with silica sand as a biomass carrier; further details on the rector specification are discussed on Makhathini [13]. As part of the initialization stage, the bioreactor was on recycle operation for $24 \mathrm{~h}$, and the bed fluidization was kept approximately $15-25 \%$ after the biofilm was developed.
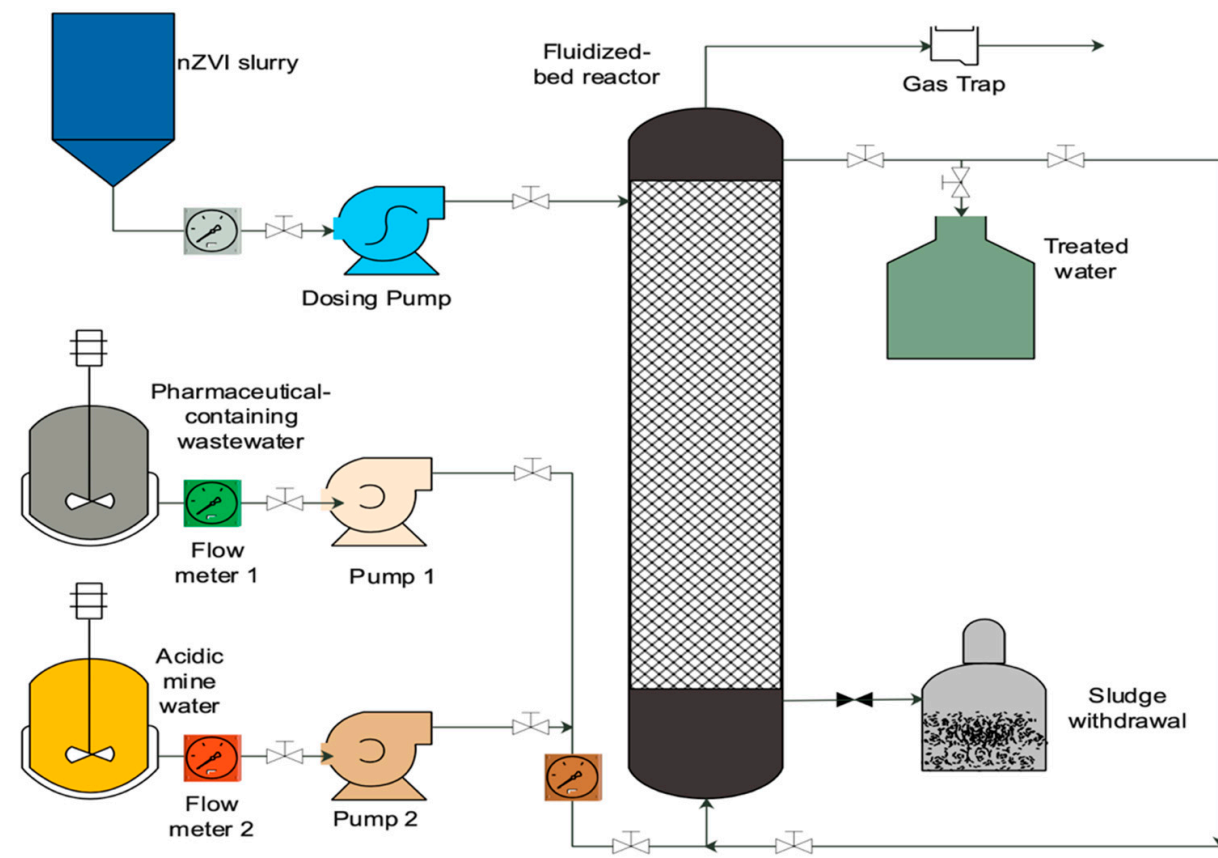

Figure 1. The experimental setup for the fluidized bed reactor. 
The hydraulic retention time (HRT) was not rigorously varied since the previous study had given some insight on its effect [13]. This study gradually reduced the HRT from 24 to 16 then later to $8 \mathrm{~h}$ while maintaining the feed rate relatively constant. The mixed stream of pump 1 and pump 2 delivery lines were only sampled four times with only a few contaminants measured, for example, $\mathrm{COD}, \mathrm{pH}, \mathrm{Zn}, \mathrm{Pb}, \mathrm{Mn}$, sulfates (Table 2). The pharmaceuticals were not measured in the reaction chamber, and the assumption was that there is no change in the initial values from HWW.

Table 2. Measurements of acid mine drainage (AMD) and hospital wastewater (HWW) at the mixing point of 2:5 $\mathrm{v} / \mathrm{v}$.

\begin{tabular}{cc}
\hline Parameter & HWW + AMD \\
\hline Zinc $(\mathrm{mg} / \mathrm{L})$ & $138 \pm 11.2$ \\
Manganese (mg/L) & $102 \pm 7.8$ \\
Lead $(\mathrm{mg} / \mathrm{L})$ & $114 \pm 10.1$ \\
$\mathrm{SO}_{4}^{2-}(\mathrm{mg} / \mathrm{L})$ & $5210 \pm 12.3$ \\
$\mathrm{COD}(\mathrm{mg} / \mathrm{L})$ & $1523 \pm 20.9$ \\
$\mathrm{pH}$ & $\pm 6.8-8.1$ \\
\hline
\end{tabular}

AMD and pharmaceutical-containing wastewater composite sample at a ratio of 2:5 was pumped to the reactor; simultaneously, the slurry of nZVI was pumped at $350 \mathrm{~mL} / \mathrm{min}$. The strength of reduction circumstance generated by $\mathrm{Fe}^{0}$ oxidation may support SRB development, which may already exist by adding highly organic pharmaceutical-containing wastewater.

\subsection{Analytical Procedures}

All samples collected from the field we filtered with 0.4 microfilters before analyses. Using the calibrated PHS-3BW pH meter maintained as recommended by the supplier, the temperature, conductivity, and $\mathrm{pH}$ were measured. To specify the alkalinity and acidity of the samples, the auto-titrator Thermo Science Orion Star T900 (Thermo Fisher Scientific Inc., Waltham, MA, USA) was used. The unfiltered samples were analyzed for COD using the APHA [29] standard methods applicable to the Hach DR3900 spectrophotometer (Hach Company, Loveland, $\mathrm{CO}$, USA). For $\mathrm{NH}_{4}-\mathrm{N}$, sulfide, sulfate, and metals, filtered samples were analyzed by APHA [29] standard methods.

A Hach DR3900 spectrophotometer was used to quantify the COD, sulfate, and sulfide. For sulfide measurement, each sample cell was filled with $10 \mathrm{~mL}$ of deionized water. Then $10 \mathrm{~mL}$ of sample was added to a second sample cell, mixed carefully to prevent sulfide loss. A $0.5 \mathrm{~mL}$ sulfide reagent one was pipetted to each sample cell, then swirled carefully. Then $0.5 \mathrm{~mL}$ of sulfide reagent two was added to each cell; again, the sample cells were then inverted to mix and then left to react for five minutes. After the time-lapse, the blank cell was used to reset the instrument (DR3900), then the cell with the sample was read.

For COD concentration measurement, the DRB200 (Hach Company, Loveland, CO, USA) was prepared by preheating the temperature to $150{ }^{\circ} \mathrm{C}$. While waiting for the instrument to get ready, a $100 \mathrm{~mL}$ sample was homogeneously mixed in a blender for 30-60 s. Using the TNT plus vials, $0.3 \mathrm{~mL}$ of sample was pipetted inside then the vial was inverted several times for proper mixing. The vials were then left in a closed preheated DRB200 reactor for $2 \mathrm{~h}$. After the lapse, the vials were taken out of the reactor, cooled to room temperature then inserted in the cell holder to produce a reading. The dissolved organic carbon (DOC) was measured using Hach standards methods.

Each sample cell was filled with $10 \mathrm{~mL}$ of sample for sulfate measurements; then, a SulfaVer 4 powder pillow was added to dissolve the powder completely. After this, the cell was left to complete the reaction for five minutes. After the time-lapse, the blank sample cell was inserted in the cell holder of the DR3900 to reset the instrument, and then the prepared sample was inserted in the cell holder to read the results. 
The BOD measuring system required $300 \mathrm{~mL}$ incubation bottles and a nitrifying inhibitor (N-Allylthiourea). About $40-100 \mathrm{~mL}$ volume of sample was added into the incubation bottles, then few drops of ATH are added to the sample, after which the BOD system was placed for five days in an incubator at $20^{\circ} \mathrm{C}$. After five days, the dissolved residual oxygen was measured for all analyzed samples to estimate the BOD.

The total dissolved nitrogen (TDN) measurements were initiated by preheating the DRB200 reactor to $103 \mathrm{C}$. A total nitrogen persulfate reagent powder pillow was added to two high range total nitrogen hydroxide digestion reagent vials. After this, $0.5 \mathrm{~mL}$ of sample was added to one of the vials, and the other vial, which was $0.5 \mathrm{~mL}$ of deionized water, was added. The prepared vials were put in the reactor for $30 \mathrm{~min}$; after time elapsed, vials were cooled down to room temperature before second total nitrogen (TN) reagent A was added. A 3-min reaction took place, then TN reagent B was added, allowing a further 2-min for the reaction. On both the prepared sample and on the blank, a $2 \mathrm{~mL}$ TN reagent $C$ was added. A 5-min reaction time was allowed then samples were read on the spectrophotometer.

For all dissolved samples, the $\mathrm{pH}$ was kept at $<2$ using concentrated $\mathrm{HNO}_{3}$, then stored at $4{ }^{\circ} \mathrm{C}$ until use. Syringe filters with a 0.45 nylon membrane were used to prepare the samples for metal concentration analysis of $\mathrm{Al}, \mathrm{Fe}, \mathrm{Cu}, \mathrm{Mg}, \mathrm{Pb}, \mathrm{Mn}$, and $\mathrm{Zn}$ before injecting into ICP-OES (Varian 720-ES, Varian Inc., Palo Alto, CA, USA). The analyses were performed in duplicate, as recommended by the USEPA protocol.

\subsection{Pharmaceutical Analysis Procedure}

Ibuprofen (98\%) and naproxen (98\%) were purchased from Sigma-Aldrich. In contrast, HPLC-grade ethyl acetate ( $>99.6 \%$ ) and HPLC-methanol (>99\%) was supplied by Macron Fine Chemicals used in the quantification of pharmaceutical compounds in the wastewater samples. Hydrochloric acid (37\%) and hexane (approx. 60\%) were purchased from Merck (SA). A flow rate of $1 \mathrm{~mL} / \mathrm{min}$ was set for the mobile phase at acetonitrile to formic acid ratio of 3:2, v:v.

A solution was made in acetonitrile containing $100 \mathrm{mg} / \mathrm{L}$ concentration for the targeted compounds, using the high-performance liquid chromatography (HPLC) (Perkin Elmer, Wellesley, MA, USA) instrument. The detection limit, quantification limit, and linearity limit were determined during this test. The method validation was tested using a deionized water sample mixed with naproxen and ibuprofen at an instant addition of 50 to 5 microliter concentration, in that order. The concentrations were determined from known values from SA WWTPs. Before each sample quantification, the solid-phase extraction (SPE) method was used to preconcentrate the sample. The method is described, and its results are presented in Section 3.6.

\subsection{Sludge Characterization}

The sludge samples were prepared for analysis using developed methods [30,31]. The sample was withdrawn at the bottom of the reactor at the end of the treatment period. The sludge was stopped from further reacting by adding $2 \%$ glutaraldehyde solution for approximately $15 \mathrm{~min}$. After this, the loose sludge was filtered using a vacuum filter with $0.5 \mu \mathrm{m}$ pores. The filtered residue was maintained under vacuum at $-70{ }^{\circ} \mathrm{C}$ for at least three days. Before measuring SEM, the samples were allowed to warm to ambient conditions. Each sample was prepared in triplicate to ensure consistency and to evaluate the reliability of the results. Characterization of the sludge used for immobilizing the biological treatment biomass was carried out [32] a field emission gun (FEG) of the Thermo Fisher Nova NanoSEM (Thermo Fisher Scientific, Waltham, MA, USA). The EDS analysis was performed using the Oxford X-ma detector with Oxford INCA software (version 4.0, Oxford Instruments, Abingdon, UK). 


\section{Results and Discussion}

There are influential factors that may drive metals concentrations and the growth of sulfate-reducing bacteria in the sulfidogenic environment for this cotreatment system with nZVI. As such, the results are presented to assess the optimum reaction conditions and influential factors thereof. These factors, include alkalinity, sulfide, organic ions, are given below.

\subsection{Batch Experiments}

Since this study continues from the published work of Makhathini et al. [13], there was no need to assess treatment process feasibility. However, nZVI in the biotreatment was to be explored for its possibility in this treatment system. The batch experiments were then conducted to evaluate the nZVI removal viability in the sulfidogenic bioreactor treating AMD and pharmaceutical-containing wastewater. The nZVI was tested for the removal of $\mathrm{Pb}(\mathrm{II}), \mathrm{Mn}(\mathrm{II})$, and $\mathrm{Zn}$ (II) ions simultaneously with sulfates as well and was found to be successful in this regard. The removal efficiencies recorded well over $90 \%$ of $\mathrm{Mn}, 92 \%$ of $\mathrm{Zn}, 94 \%$ of $\mathrm{Pb}$, and $80 \%$ of sulfates in $60 \mathrm{~min}$ (Figure 2).

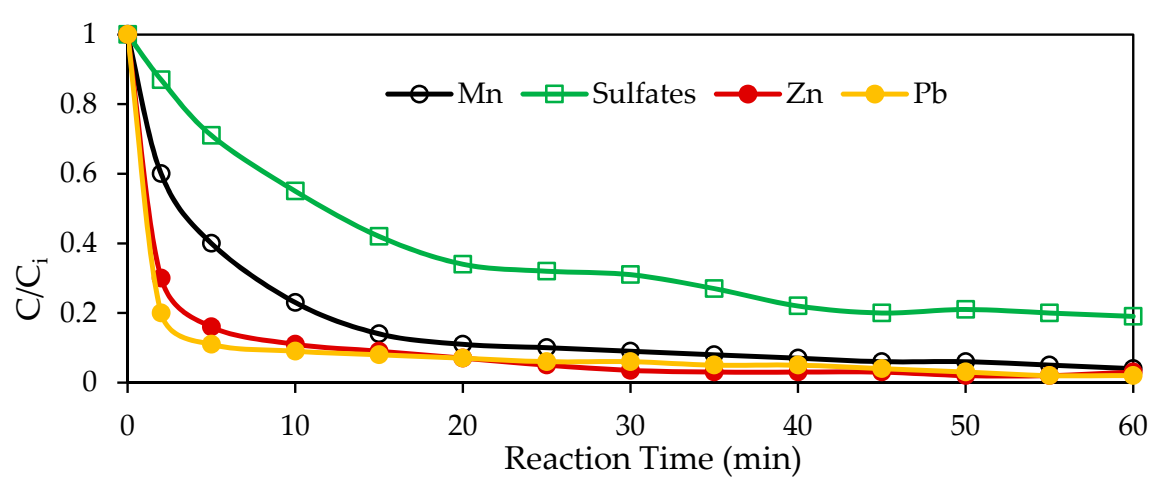

Figure 2. Removal of heavy metals from a mixture of acid mine drainage and pharmaceuticalcontaining wastewater at an initial $\mathrm{pH}$ of 5.6, using nano zero-valent iron (nZVI).

Guo et al., [17] warn that the presence of high nZVI concentration may potentially trigger oxidative stress on bacterial development. In agreement, the study of Kumar et al. [16] stated that when the nZVI dosage exceeded $1.0 \mathrm{~g}$ in a liter, the $\mathrm{SO}_{4}{ }^{2-}$ the decline was significantly inhibited. While Velimirovic et al. [33] suggest that the microbial community activity can be hindered if the addition of nZVI concentration exceeds $0.05 \mathrm{~g} / \mathrm{L}$. In contrast, Kirschling et al. [34] demonstrate that a sufficient concentration of nZVI could stimulate SRB development, and it is helpful to eliminate pollutants. Since this current study sought to reduce the heavy metals and the sulfates, it is for this reason that the optimization of the nZVI dosage was initiated (Figure 3).

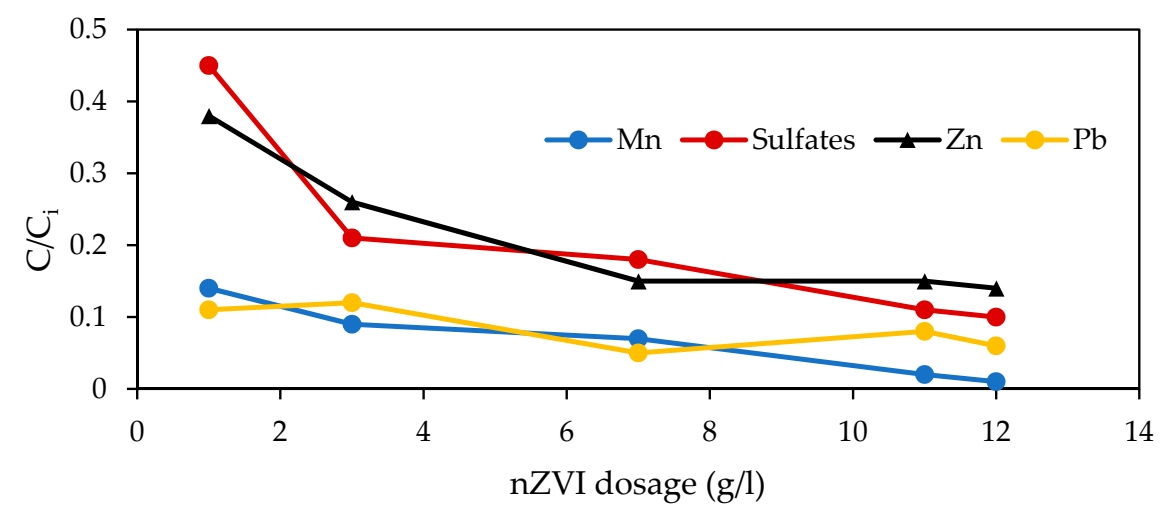

Figure 3. The dosage of nZVI with time testes over $24 \mathrm{~h}$. 


\subsection{Reaction Mechanism}

Organic carbon, mainly from the HWW, serves as the energy source for the sulfate reduction and removing metals from AMD by SRB in the bioremediation process. However, in the nZVI with HWW + AMD treatment configuration, hydrogen and Fe(II) ions originating from $\mathrm{Fe}^{0}$ oxidation may also act as an energy source for the sulfate reduction [33] in a shorter time. In a case where heavy metals are involved, as is in this study, several pathways of their removal are suggested by Dong et al. [14] as biosorption, co-precipitation, reductive, and sulfide precipitation (Figure 4).

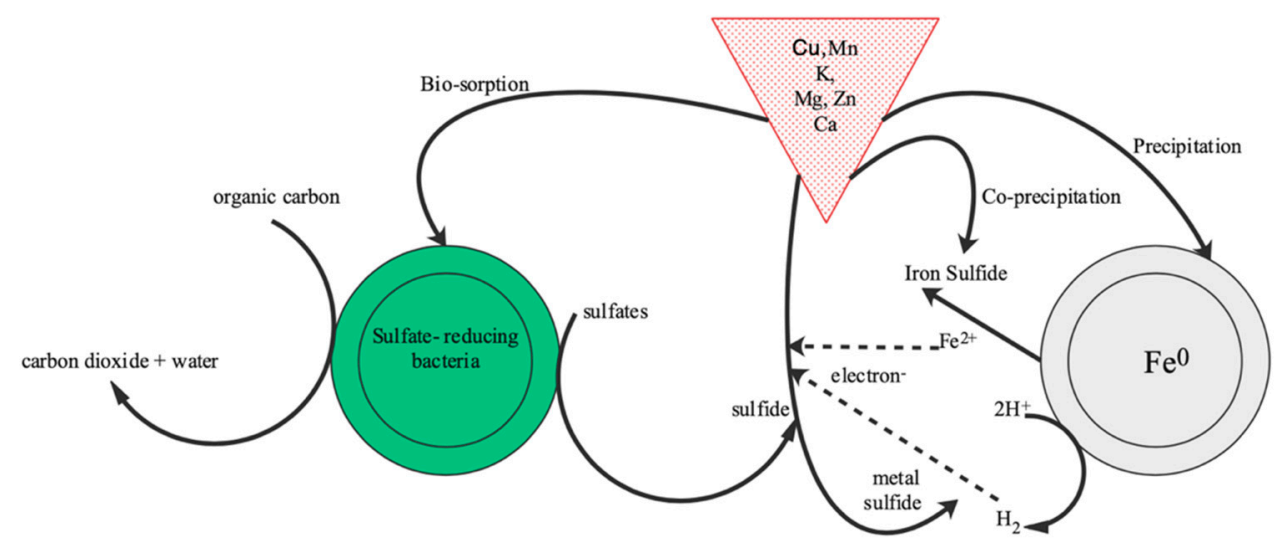

Figure 4. The elimination pathways of heavy metals in the (HWW+AMD)-nZVI system.

The SRB cell membrane and extracellular synthetic polymers will directly touch the heavy metals [35] and adsorb them by physical or chemical adsorption to the nanoparticle membrane [36]. The ferrous ions released from $\mathrm{Fe}^{0}$ corrosion may react to produce iron sulfides, which are otherwise relatively effective adsorbents for heavy metals [37]. For the reductive precipitation, as a reducing agent, nZVI reduces certain heavy metals like $\mathrm{Pb}^{2+}$, $\mathrm{Zn}^{2+}$, and $\mathrm{Mn}^{2+}$, then develops insoluble metal precipitates, disintegrate heavy metals, and mitigate environmental hazards [38]. The $\mathrm{SO}_{4}{ }^{2}$ can also be decreased by SRB metabolism to the sulfide, which may oxidize to the sulfide precipitates with metal ions [39]. Notably, the above removal pathways occur concurrently. However, the nZVI remedial strategy's primary removal pathway is reductive precipitation and adsorption, a critical elimination pathway in the SRB treatment process [40].

\subsection{Influence of $\mathrm{pH}$ and the Source of Carbon}

As mentioned earlier, this study used hospital wastewater as the organic substrate for $\mathrm{SO}_{4}{ }^{2-}$ and microbial growth, basically using the following reaction Equation (4):

$$
\operatorname{organics}(\mathrm{COD})+\mathrm{SO}_{4}^{2-}+\mathrm{H}_{2} \mathrm{O} \rightarrow \mathrm{H}_{2} \mathrm{~S}+2 \mathrm{HCO}_{3}^{-}
$$

COD mass for desulfurization was based on the stoichiometry of $1 \mathrm{~g}$ of $\mathrm{SO}_{4}{ }^{2}$ be reduced, $0.67 \mathrm{~g}$ of COD is desired [41]; thus, the alkalinity of approximately $1.042 \mathrm{~g}$ is formed. The SRB development is optimal at a $\mathrm{pH}$ of 6.5 but still favorable from 5-9 [14]. In this study, the $\mathrm{pH}$ was at an average of 6.4, at least for phase II and III. In phase I, the $\mathrm{pH}$ was averaging at 6.9; thus, the metal removal was rapid. The addition of $\mathrm{Fe}^{0}$ raises the alkalinity value within a turn, improves the activity development of SRB. The response in alkalinity and $\mathrm{pH}$ is presented in Figure 5. Moreover, after phase I, which was mainly bacterial acclimation and reaching sorption capacity, from phase II, reducing conditions caused by high SRB start to increase the alkalinity, proving metal sulfide precipitation $[42,43]$. 


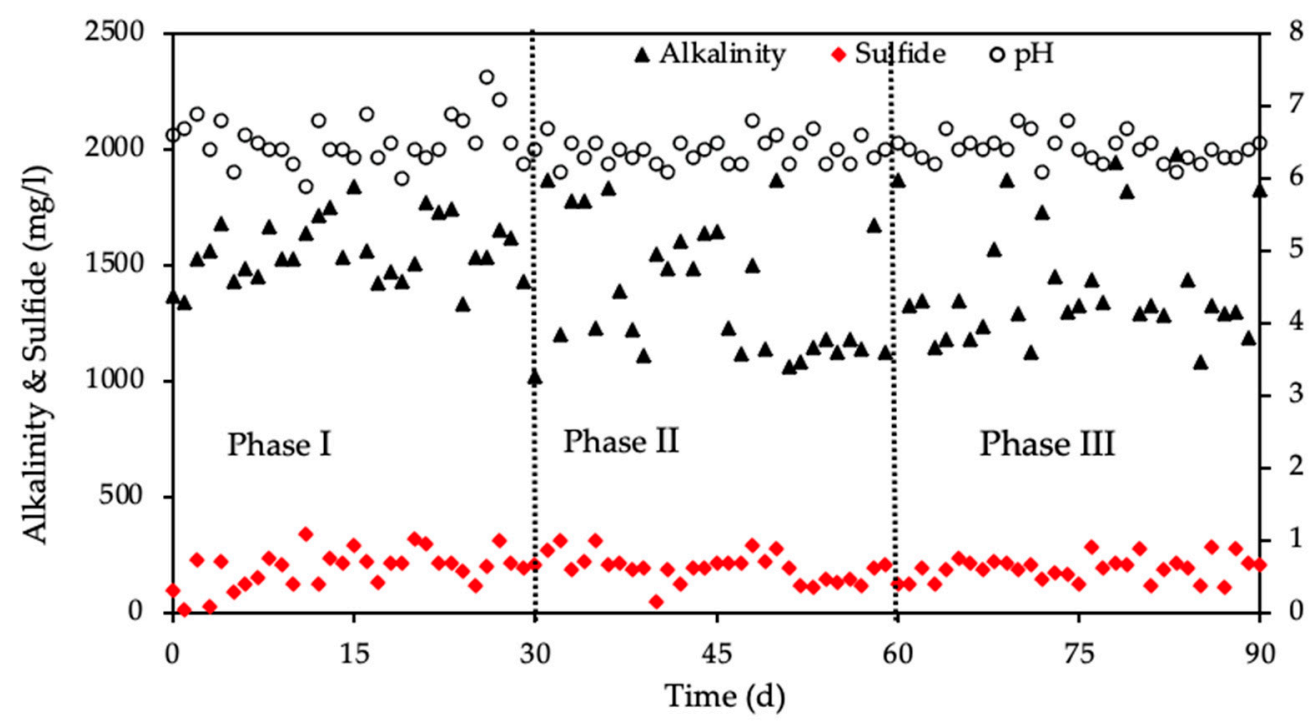

Figure 5. Alkalinity, $\mathrm{pH}$, and sulfide response with time in the fluidized bed reactors.

When Kumar et al. [16] examined the impact of oxidation-reduction potential and the $\mathrm{pH}$ on the strength of $\mathrm{Zn}$ (II) precipitates in the ZVI and sulfate-reducing bacteria with ZVI systems. They found that column experiments signified Zn precipitates' strength as less sensitive to ORP change but significant sensitivity to $\mathrm{pH}$ change. Sulfide concentration was recorded as low as $<0.05 \mathrm{mg} / \mathrm{L}$ for most of phases II and III. Simultaneously, the alkaline production increased during phases II and III, which could be attributed to a reduction in sulfate concentration.

The initial $\mathrm{pH}$ on $\mathrm{SO}_{4}{ }^{2-}$ reduction and final $\mathrm{pH}$ indicates that $\mathrm{Fe}^{0}$ positively affects $\mathrm{pH}$ and may increase it to support the SRB activity. In $\mathrm{Fe}^{0}$ enhanced processes, like this current study, alkalinity may be generated by anoxic corrosion of $\mathrm{F}^{0}$ Equation (5) and $\mathrm{SO}_{4}{ }^{2-}$ Equation (6) since both equations use hydrogen ions.

$$
\begin{aligned}
& \mathrm{Fe}^{0}+\mathrm{H}_{2} \mathrm{O} \rightarrow \mathrm{Fe}^{2+}+\mathrm{H}_{2}+2 \mathrm{OH}^{-} . \\
& \mathrm{SO}_{4}^{2-}+4 \mathrm{H}_{2}+\mathrm{H}^{+} \rightarrow \mathrm{HS}^{-}+4 \mathrm{H}_{2} \mathrm{O}
\end{aligned}
$$

Nitrogen and organic carbon concentrations were almost certainly influenced by precipitation in phase I of the treatment system. An overall observation of BOD, DOC, and TDN proved a decrease over the first 30 days, phase I (Figure 6). It is most likely that the bacterial $\mathrm{SO}_{4}{ }^{2-}$ reduction facilitated processing of the BOD and DOC [12]. In the FBR, the inorganic nitrogen was introduced from the HWW sample in ammonia form; at the end of phase II, 9-28\% $\mathrm{NH}_{4}^{+}$was measured. The DOC concentrations were evidently following the metal concentration decline trend. Nitrate and nitrite were recorded to be reasonably low at $\leq 0.1 \mathrm{mg} / \mathrm{L}$ and $\leq 5 \mathrm{~g} / \mathrm{L}$, in this order. 


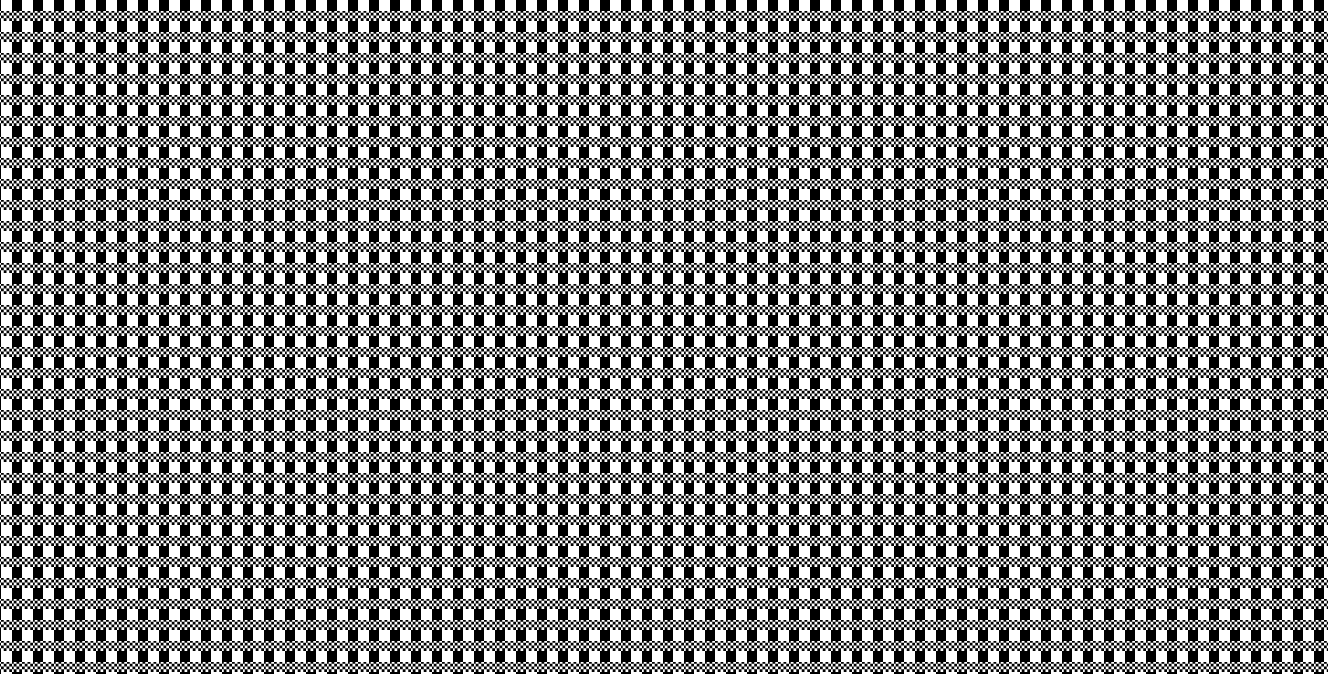

Figure 6. Total dissolved nitrogen (TDN), dissolved organic carbon (DOC) and organic matter (COD) concentrations at different phases of treatment.

\subsection{Effects of COD and Sulfates}

Throughout the first phase of treatment, there was a substantial reduction of sulfates and COD concentrations (Figure 7). Although the removal of metals and phosphates were high, $88 \% \mathrm{PO}_{4}{ }^{3-}$, sulfate, and other organic matter were moderately reduced. Smyntek et al. [10] highlighted that $\mathrm{SO}_{4}{ }^{2-}$ reduction rates are likely to be affected by establishing the microbial ecosystem or lack thereof. Evidently, during phase I, the FBR was not afforded enough time to develop a microbial ecosystem, which may have resulted in complete $\mathrm{SO}_{4}{ }^{2-}$ reduction [44]. In addition, there is well-documented literature supporting the fact that sulfate reduction is dependent on COD, and the ratio of $\mathrm{SO}_{4}{ }^{2-} / \mathrm{COD}$ changes with the type of organics available $[45,46]$.

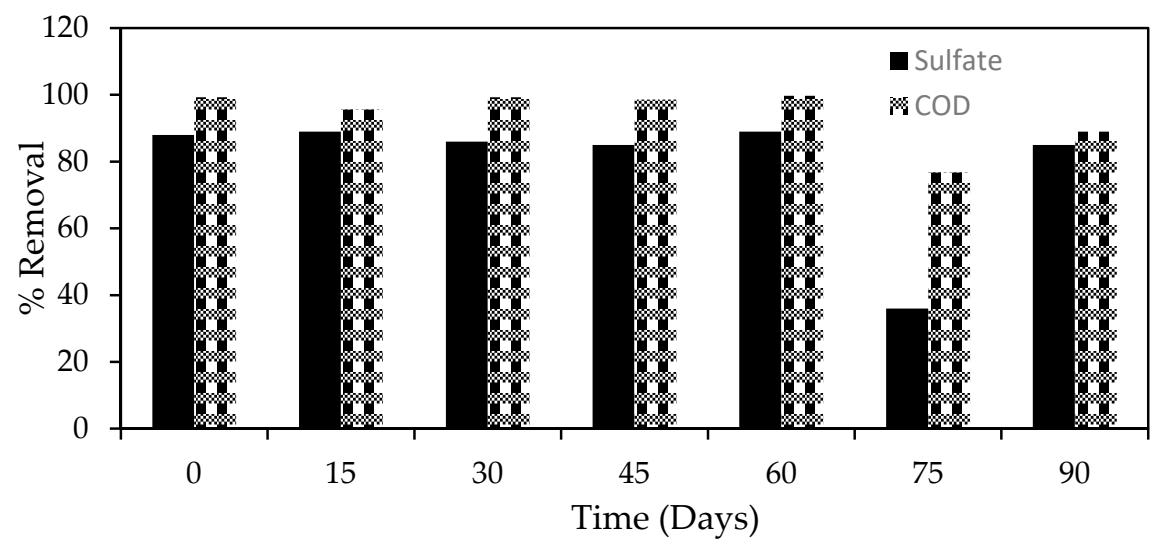

Figure 7. The removal rate for sulfate in comparison to COD.

The second phase of treatment confirmed the bioreactor's reducing setting was given by redox potential measurements of -101 to $-190 \mathrm{mV}$ depending on the COD level on the FBR. Since the hospital wastewater samples had higher total suspended solids (TSS) than mine water samples, 478 and $2 \mathrm{mg} / \mathrm{L}$, respectively, TSS significantly increased in the FBR during phase I. However, in phase II there was a reduction in TSS to the range of 5-24 gm/L. On the contrary, the total dissolved solids (TDS) decreased s phase I due to subsequent phase I formation of precipitates in the FBR. After this, there was no significant reduction of TDS in phase II observed. 


\subsection{Reactor Monitoring Using $E_{h}$}

The nZVI was rapidly mixed using the laboratory mixer before its use to reduce conditions by even dispersing the resin in water. As such, the $E_{h}$ in the FRB reduces below $-310 \mathrm{mV}$ instantly after the introduction of nZVI. There was no agitation in the FBR; influent was fed from the bottom, stabilizing fluidization and even dispersion on nZVI in the reactor. The control of the bed volume was carefully controlled by adjusting the influent while optimizing the dosage on nZVI (Figure 2). The Eh of the reactor contents was also used to monitor the FBR treatment performance, making necessary adjustments to nZVI dosage and the influent feed. It was evident that an automatic control strategy to regulate the nZVI and feed pump responding to Eh value could have made the treatment system more stable. This system's manual operation may compromise the reactor's performance, as there are times when the time elapsed without any response from the pumps, whereas the Eh was way below $-200 \mathrm{mV}$. Li et al. [47] advised monitoring redox-potential in the nZVI enhanced reactor promises a quick, consistent, and efficient approach to managing the treatment performance. Consequently, by managing the treatment system, there may be less need for nZVI and, therefore, lower the cost of treatment [48].

\subsection{Metal Concentration Removal}

Two key factors may decide the toxic effects on metals for a biological treatment process that depends on SRB: the type of metals and their associated concentration. As such, the treatment process's performance is assessed by $\mathrm{Fe}^{2+}, \mathrm{Zn}^{2+}$, and $\mathrm{Mn}^{2+}$ removal, as highlighted in Table 3. The average concentration of $\mathrm{Zn}(\mathrm{II})$ was lowered from 144 to $0.55 \mathrm{mg} / \mathrm{L}$ and $\mathrm{Mn}(\mathrm{II})$ from 113 to $0.21 \mathrm{mg} / \mathrm{L}$ in the final reactor discharge, achieving an average of more than $99.8 \%$ removal efficiency. The results suggest that during phase I, the metal removal may be attributed to sorption on organic waste and precipitation of hydroxides and carbonates [49].

Table 3. Metal concentrations removal and standard deviation (SD).

\begin{tabular}{|c|c|c|c|c|c|c|c|c|}
\hline Period & Days & & $\mathbf{P b}$ & $\mathrm{Cu}$ & Zn & $\mathbf{F e}$ & $\mathrm{Ca}$ & Mn \\
\hline \multicolumn{9}{|c|}{ Total metals in influent $(\mathrm{mg} / \mathrm{L})$} \\
\hline \multirow[t]{2}{*}{$\mathbf{I}$} & $0-30$ & Concentration & 33.12 & 112 & 421 & 3112 & 212 & 355 \\
\hline & & SD & 0.11 & 1.1 & 3.4 & 17 & 1.3 & 0.1 \\
\hline \multirow[t]{2}{*}{ II } & $31-60$ & Concentration & 18.1 & 59 & 81 & 589 & 119 & 117 \\
\hline & & SD & 9 & 0.2 & 2.1 & 7 & 1.2 & 0.2 \\
\hline \multirow[t]{2}{*}{ III } & $61-90$ & Concentration & 12 & 21 & 44 & 187 & 211 & 45 \\
\hline & & SD & 4 & 1.1 & 1.1 & 12 & 1 & 2.1 \\
\hline \multicolumn{9}{|c|}{ Total metals in effluent (mg/L) } \\
\hline \multirow[t]{2}{*}{ I } & $0-30$ & Concentration & 12.1 & 1.02 & 0.2 & 11.9 & 2.1 & $<0.02$ \\
\hline & & SD & 1.9 & 0.1 & 0.01 & 1.3 & 0.09 & $<0.02$ \\
\hline \multirow[t]{2}{*}{ II } & $31-60$ & Concentration & 9.9 & 1.12 & 0.7 & 17 & 1.8 & $<0.05$ \\
\hline & & SD & 2.3 & 0.4 & 0.3 & 1.4 & 0.01 & $<0.05$ \\
\hline \multirow[t]{2}{*}{ III } & $61-90$ & Concentration & - & $<0.05$ & $<0.05$ & 19 & $<0.05$ & $<0.05$ \\
\hline & & SD & - & - & - & 1.1 & - & - \\
\hline
\end{tabular}

For the whole of 90 days experimental run, the influent concentration of $\mathrm{Mn}, \mathrm{Fe}$, and $\mathrm{Zn}$ was spiked up and at times exceeded 350, 5000, and $420 \mathrm{mg} / \mathrm{L}$, respectively. The spike was done deliberately to shock the system for simulation of the field experience. Regardless of these simulated unsteady state conditions, the effluent was consistently achieving less than $2 \mathrm{mg} / \mathrm{L}$ concentration for all metals, like $\mathrm{K}, \mathrm{Na}, \mathrm{Ca}$, and $\mathrm{Mg}$. These results demonstrate the reliability of the treatment process. Table 3 demonstrates that $\mathrm{Pb}, \mathrm{Mn}$, and $\mathrm{Zn}$ were removed $96 \%,>80 \%$, and $92 \%$, respectively, in the first treatment phase. This performance may be due to mine water-binding with organic molecules $[26,50]$. On the other hand, the sulfates were reduced by $70 \%$ in phase I, which is lower than the previous studies published for similar FBR application in the absence of nZVI [13]. At the 
end of phase III, the increase in Fe could well be due to microbial Fe decrease of $\mathrm{FePO}_{4}$ and $\mathrm{Fe}(\mathrm{OH})_{3}[12,51]$. FeS precipitated due to the sulfate-reducing environment that is dominant in this period [52]. Lastly, metal biosorption to the organic molecules related to the metabolism mechanism could be the reason for metal removal $[44,53,54]$.

Having incorporated $\mathrm{nZVI}$ as an enhancement tool for removing a wide variety of contaminants from chemical solutions; however, the current study focused on evaluating material efficiency for the bioremediation process of two real streams. The performance of nZVI for pollution prevention for groundwater depends on bioremediation as a parallel method to hinder metalloid and metal discharge [47]. Nonetheless, reactions that are microbially facilitated with Fe may assist and prevent removal reactions. Like, ferric ion decreasing microorganisms, it may lessen most high-valence metal pollutants, i.e., $\mathrm{Cr}$, over intended enzymatic decrease and through unintended reduction catalyzed by biogenic ferrous ion [55].

\subsection{Pharmaceutical Compounds Assessment}

The chromatograms generated for the separation of naproxen and ibuprofen compounds are shown in Figure 8. These pharmaceutical compounds were separated using the HPLC column (C18) with the resolution values above 1.4. As described by Madikizela and Chimuka [56], the sensitivity of the method was measured by the limit of quantification (LOQ) and limit of detection (LOD).

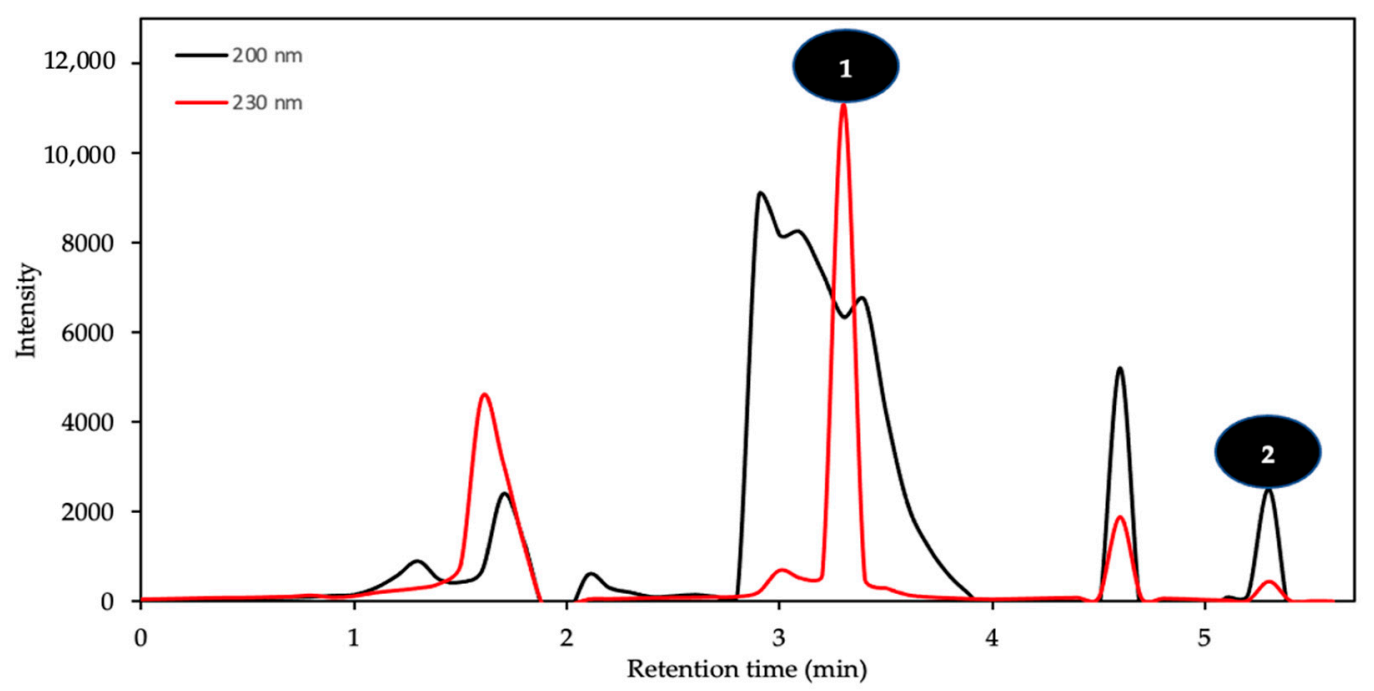

Figure 8. Naproxen (1) and ibuprofen (2) chromatograms $1 \times 10^{3} \mu \mathrm{g} / \mathrm{L}$ at 200 and $230 \mathrm{~nm}$.

The results shown in Table 4 demonstrate that this method may be applied to target low levels of compounds, i.e., $\mu \mathrm{g} \mathrm{L}^{-1}$. Published studies quantified the same compounds using HPLC and diode array detection [56-58]. Solid-phase extraction (SPE) efficiency validated the analytical method, which was higher than 80 percent for naproxen and ibuprofen compounds. The linearity was found to be $\mathrm{r}^{2} \geq 0.97$, which demonstrates the acceptable method accuracy. The values of the SPE efficiency are given in standard deviation to ensure method precision further. When looking at the SPE production and linearity, the bioreactor effluent is identical to deionized water. Table 4 sets out the results of the validation. 
Table 4. Analytical method validation.

\begin{tabular}{ccccc}
\hline $\begin{array}{c}\text { Pharmaceutical } \\
\text { Matrix }\end{array}$ & Effluent & & Deionized & \\
\hline & Ibuprofen & Naproxen & Ibuprofen & Naproxen \\
\hline SPE efficiency & $82 \pm 3.4$ & $81 \pm 8.7$ & 83 & 84 \\
$(\%)$ & $1.2-1.9$ & $0.2-1.1$ & 0.3 & 0.2 \\
Detection limit & $0.5-1.4$ & $2.3-3.7$ & 0.6 & 1.2 \\
Quantification & 0.98 & 0.99 & 0.99 & 0.99 \\
limit & & & & \\
$\mathrm{r}^{2}$ & &
\end{tabular}

The pharmaceutical compounds like ibuprofen and naproxen are in the class of nonsteroidal anti-inflammatory drugs [5]. These organic compounds are acidic and polar; naproxen and ibuprofen have a pKa value of 4.2 and 4.9 , in that order [59]. These compounds' polarity nature makes it easier for them to escape the wastewater process and contaminate the receiving waters.

Pharmaceutical removal was not as successful as was initially anticipated; however, Figure 9 demonstrates a progressive increase in the removal as time lapsed. These results are worse than the previous study on cotreatment of AMD and HWW, but with no nZVI as an enhancing reagent. In this previous study, ibuprofen and naproxen achieved $51 \%$ and $34 \%$ removal, respectively, at the end of 90 days [13]. In this current work, the maximum removal achieved for ibuprofen is $33 \%$. Again, the main factor for this low removal is not clearly understood yet, and it could be that biomass in the FBR consists of microorganisms that are utilizing pharmaceuticals as organic substrates.

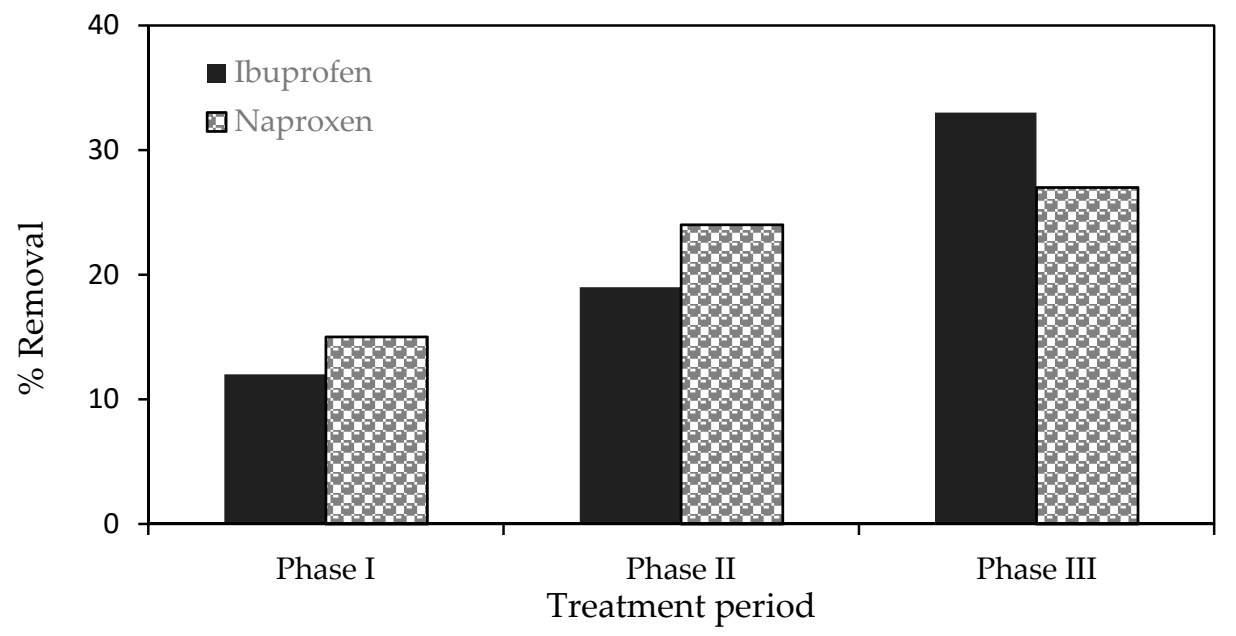

Figure 9. The final removal for naproxen and ibuprofen at the end of each treatment period.

\subsection{Sludge Management with nZVI}

First, degradation efficiency for nZVI from the FBR is assessed by the ratio of heavy metals to the amount of nZVI dosed in the system. The pharmaceuticals removal was not reported here in the sludge as they showed less to no removal within this system. The removal load for Zn and Mn was approximately $144 \mathrm{mg} \mathrm{Pb} / \mathrm{g} \mathrm{Fe}, 198 \mathrm{mg} \mathrm{Zn/g} \mathrm{Fe}$ and $207 \mathrm{mg} \mathrm{Mn} / \mathrm{g} \mathrm{Fe}$, correspondingly. By the end of the 90 days treatment period, the combined load of metal ions removed for nZVI was estimated $>600 \mathrm{mg}$ metals/g Fe, which is higher than other reports on resins usually used for heavy metal separation.

As seen in Figure 10e, an elevated concentration of toxic elements was detected, which shows that nZVI is a flexible material for metal extraction [47]. However, the image of the morphology in the sludge was different than in other studies that used SRB and nZVI $[60,61]$ in that it was not rod-shaped. It was expected that there would be small 
particles on the surface of the cells, which are called extracellular biofilms. However, not identifying the extracellular polymeric substance responding to toxic compounds may be due to less availability of microorganisms [62] at the end of the treatment. As such, bacterial biofilms act as nucleation sites for sulfide mineral precipitation [63]; however, in this study, the SEM was only done at the end of phase III (at day 90), which may mean there were no longer available sites for precipitation. In addition, the inadequate removal of naproxen and ibuprofen could be attributed to no available nucleation sites.
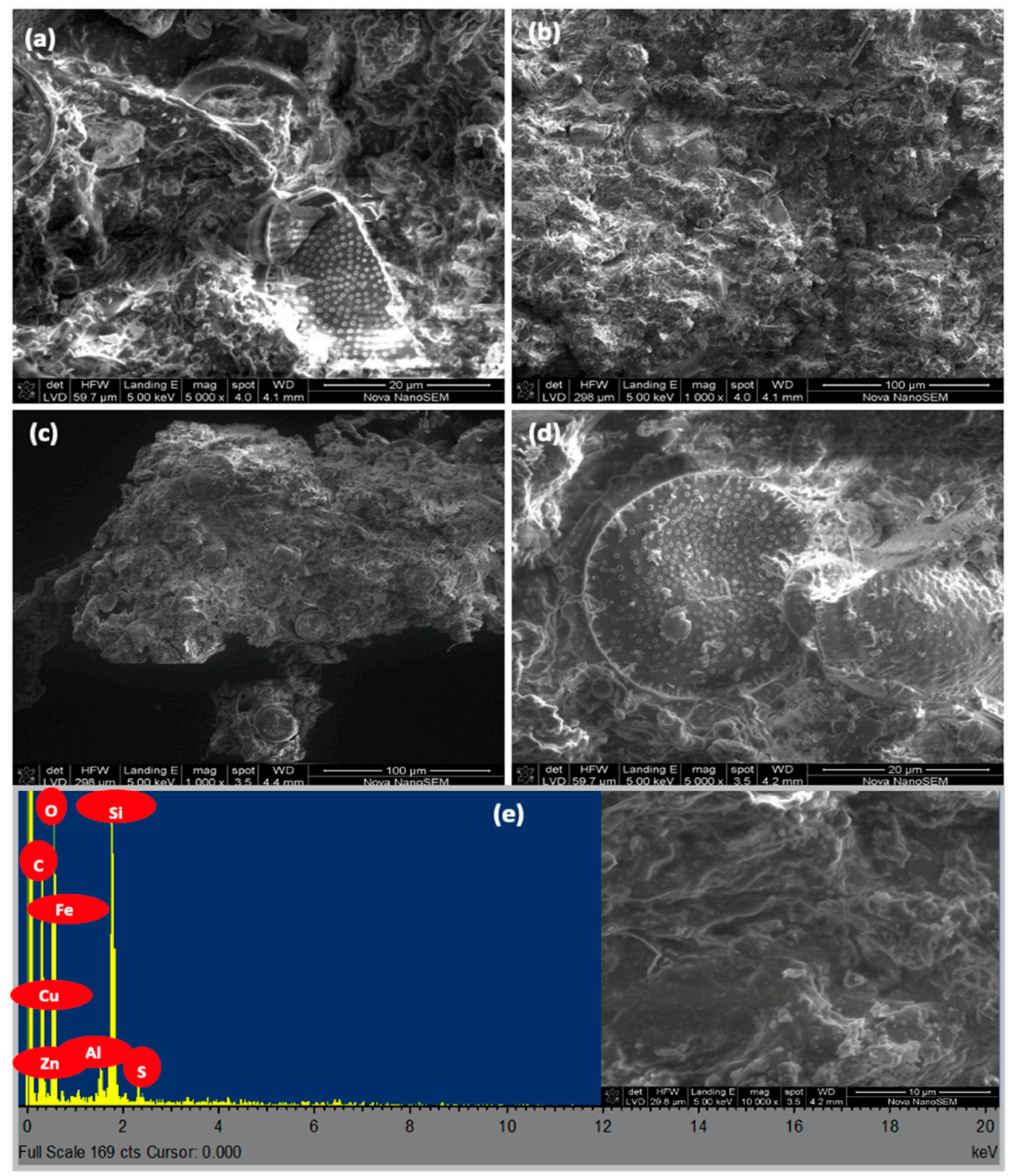

Figure 10. SEM photomicrograph of the sludge sample from the fluidized-bed reactor (FBR) (a,b) at 45 days; (c,d) at the end of 90 days and chemical element spectrum of the sludge (e) with an EDS scan inserted.

Since the study could not assess the solids recirculation of the spent nZVI because of its attachment to the silica sand, the hydraulic retention time was kept between 6 and $8 \mathrm{~h}$. All the initially detected elements in the mine water samples were also found in the sludge (Figure 10). Both SEM and EDS analysis was performed to further characterize the sludge; when performed alone, the EDS has received an unwelcome reputation as a "semiquantitative" technique [31]. Furthermore, Figure 10a,d illustrates the SEM photomicrograph image of the sludge harvested in the FBR at the end of phase III. The EDS qualitative 
analysis highlighted signals $\mathrm{C}, \mathrm{O}, \mathrm{Al}, \mathrm{Fe}, \mathrm{Mn}$, and $\mathrm{Si}$ on the solid phase, in addition to small quantities of $\mathrm{Zn}$ in a range of $0.1-1 \%$. These results are slightly different from Kumar et al. [64], who used zero-valent iron to enhance sulfate reduction, but permeable reactive barriers. Silicon originates from the silica sand used as biomass at the initial stage of the treatment.

\subsection{General Overview of the nZVI Cost}

One of the critical factors when choosing a treatment option after efficacy is the cost. The nZVI specifically is easily re-usable in the treatment process, then the dosage is reduced, which minimizes the consumption of fresh material. The reaction times are shortened, where nZVI is used to enhance the treatment process. Moreover, the process is simple in terms of monitoring since there are a few parameters to control. However, for a developing country like South Africa, this technology is yet to gain traction. It is an active treatment, energy-intensive since the mixing of nZVI powder makes slurry before use. South Africa is still struggling with energy reserves; this method may still be challenging to employ commercially. Even though some researchers assure that the effluent quality may offset the treatment cost [47].

\subsection{The Overall Pollution Reduction in AMD}

Regarding the treatment system performance, the sulfidogenic fluidized bed reactors removed over $85 \%$ of each metal measured in the initial samples before treatment (Figure 11). The iron removal rate was consistent if not superior with other SRB reactors $[20,30,65,66]$, and achieved an average of $97 \%$. At the observed removal rates, the Fe concentrations meet the water quality objectives. The removal of Mn was observed to be $90 \%$, and this result was satisfactory since the manganese retention was evident in the FBR during phase I and phase II of treatment. As observed by Clyde et al. [51], the retention could have resulted from Mn sorption in the FBR. The removal mechanism may also be attributed to $\mathrm{MnCO}_{3}$ and said not completely to remove manganese from the solution [67]. For copper, the removal rate was $88 \%$ in the FBR and may be considered a low removal compared to the other pollutants. However, the results are similar to the bench-scale study using SRB done by Cylde et al. [51] since copper was retained in the FBR throughout the treatment process. In terms of zinc removal, the average was found to be $92 \%$. The result was satisfactory and better than a pilot-scale study done by Jarvis et al. [68]. The Zn result is somewhat $\mathrm{pH}$-dependent; it has been reported that zinc removal increased with elevated $\mathrm{pH}>4$ [69].

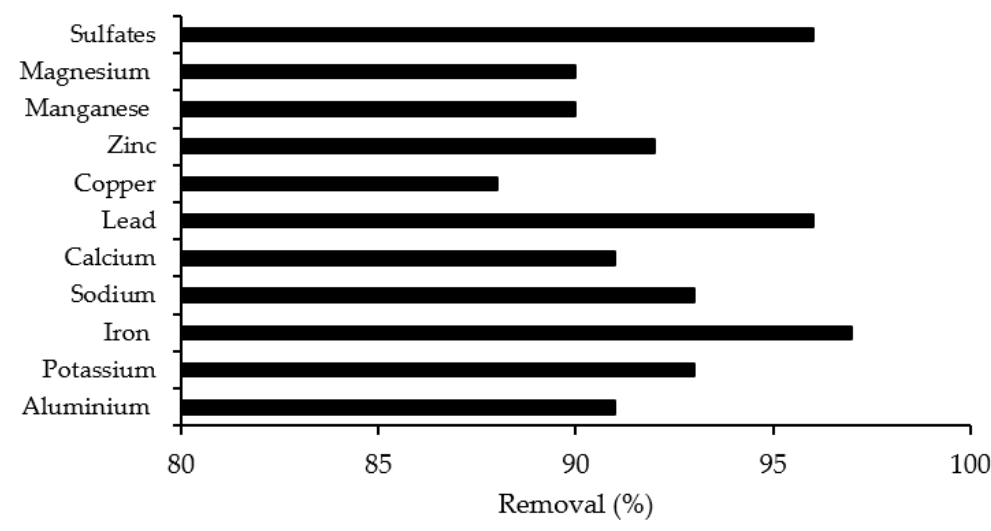

Figure 11. The average percent removal for pollutants, specifically in the FBR, over the treatment period.

Overall, the treatment process observed that the $\mathrm{SO}_{4}{ }^{2-}$ concentration was gradually reducing every day, which was expected as per the study hypothesis. The effluent results showed an average of $96 \%$ decrease throughout the treatment process, with an average 
area of removal rate of $7 \mathrm{~g} / \mathrm{m}^{2} / \mathrm{d}$. This system proved to be highly effective with sulfate removal, one of the persistent pollutants in mine water.

\section{Conclusions}

The degradation of pharmaceuticals in wastewater has recently received considerable attention as a potential solution to the growing demand for strict effluent standards. This work demonstrated nanoscale zero-valent iron's efficacy as an enhancing element for remediating real mine water and pharmaceutical-containing wastewater from a hospital. The laboratory-scale fluidized-bed reactor proved to simultaneously remove metal ions, like $\mathrm{Mn}$ and $\mathrm{Zn}$, from wastewater while achieving a significant reduction of $\mathrm{SO}_{4}{ }^{2-}$ and organic matter (COD, BOD, DOC), TDN. In terms of the treatment performance, effluent $\mathrm{pH}$ values were generally higher than the FBR influent. The generation of alkalinity corresponding to sulfate reduction in the sulfidogenic reactor demonstrates that SRB could maintain the biological activities. The cotreatment in FBR could be used to treat pharmaceutical wastewater containing nonsteroid inflammatory compounds and COD reduction of over $90 \%$, suggesting biomass had acclimated to the compounds. The overall treatment effectiveness for AMD was found to be at an average of $92.5 \%$. Since the COD degradation is directly affected by the complexity and variability of the hospital wastewater, long HRT in the FBR may lessen the effects. The reactor contents' redox potential was used to monitor the FBR treatment performance, making necessary adjustments to nZVI dosage and the influent feed. For the future, it is recommended that an automatic control strategy to regulate the $\mathrm{nZVI}$ and feed pump responding to $\mathrm{E}_{\mathrm{h}}$ value be used to make the treatment system more stable. An investigation of the nZVI activation procedure may be necessary to enhance the reactivity of its surface-passivated particles in order to explore pharmaceutical removal in that case further. Finally, building from the work of Laber et al. [23], where they constructed a wetland to treat hospital wastewater, with such rich literature on wetlands from the point of treating AMD [7,24-26], this work contributes to a possibility of amalgamating the two-waste stream in one wetland.

Author Contributions: Conceptualization, T.P.M. and J.M.; methodology, T.P.M.; validation, T.P.M.; formal analysis, T.P.M.; investigation, T.P.M.; data curation, T.P.M.; writing—original draft preparation, T.P.M.; writing-review and editing, T.P.M., J.M. and B.F.B.; supervision, J.M. and B.F.B.; project administration, T.P.M., J.M. and B.F.B.; funding acquisition, T.P.M. and B.F.B. All authors have read and agreed to the published version of the manuscript.

Funding: This research was funded by the National Research Foundation, reference number TTK180412319899.

Institutional Review Board Statement: Not applicable.

Informed Consent Statement: Not applicable.

Data Availability Statement: Not applicable.

Acknowledgments: Authors are thankful to the Center for Imaging and Analysis, the University of Cape Town for SEM/EDC sample analysis. The authors thank Zimbini Ngcingwana (University of KwaZulu Natal) for her assistance with metal analysis.

Conflicts of Interest: The authors declare no conflict of interest.

\section{References}

1. Masindi, V.; Akinwekomi, V.; Maree, J.P.; Muedi, K.L. Comparison of mine water neutralisation efficiencies of different alkaline generating agents. J. Environ. Chem. Eng. 2017, 5, 3903-3913. [CrossRef]

2. Masindi, V.; Muedi, K.L. Environmental contamination by heavy metals. Heavy Met. 2018, 10, 115-132. [CrossRef]

3. Naidoo, S. Acid Mine Drainage in South Africa: Development Actors, Policy Impacts, and Broader Implications; Springer International Publishing AG: Cham, Switzerland, 2017.

4. Gumbi, B.P.; Moodley, B.; Birungi, G.; Ndungu, P.G. Detection and quantification of acidic drug residues in South African surface water using gas chromatography-mass spectrometry. Chemosphere 2017, 168, 1042-1050. [CrossRef] 
5. Madikizela, L.M.; Chimuka, L. Simultaneous determination of naproxen, ibuprofen and diclofenac in wastewater using solidphase extraction with high performance liquid chromatography. Water Sa 2017, 43, 264-274. [CrossRef]

6. Chonova, T.; Keck, F.; Labanowski, J.; Montuelle, B.; Rimet, F.; Bouchez, A. Separate treatment of hospital and urban wastewaters: A real scale comparison of effluents and their effect on microbial communities. Sci. Total Environ. 2016, 542, 965-975. [CrossRef] [PubMed]

7. Johnson, K.L.; Younger, P.L. The co-treatment of sewage and mine waters in aerobic wetlands. Eng. Geol. 2006, 85, 53-61. [CrossRef]

8. McCullough, C.D.; Lund, M.A.; May, J.M. Field-scale demonstration of the potential for sewage to remediate acidic mine waters. Mine Water Environ. 2008, 27, 31-39. [CrossRef]

9. Strosnider, W.H.J.; Winfrey, B.K.; Nairn, R.W. Novel passive co-treatment of acid mine drainage and municipal wastewater. J. Environ. Qual. 2011, 40, 206-213. [CrossRef]

10. Smyntek, P.M.; Chastel, J.; Peer, R.A.M.; Anthony, E.; McCloskey, J.; Bach, E.; Wagner, R.C.; Bandstra, J.Z.; Strosnider, W.H.J. Assessment of sulphate and iron reduction rates during reactor start-up for passive anaerobic co-treatment of acid mine drainage and sewage. Geochem. Explor. Environ. Anal. 2018, 18, 76-84. [CrossRef]

11. Strosnider, W.H.J.; Winfrey, B.K.; Nairn, R.W. Alkalinity generation in a novel multi-stage high-strength acid mine drainage and municipal wastewater passive co-treatment system. Mine Water Environ. 2011, 30, 47-53. [CrossRef]

12. Strosnider, W.H.J.; Winfrey, B.K.; Peer, R.A.M.; Nairn, R.W. Passive co-treatment of acid mine drainage and sewage: Anaerobic incubation reveals a regeneration technique and further treatment possibilities. Ecol. Eng. 2013, 61, 268-273. [CrossRef]

13. Makhathini, T.P.; Mulopo, J.; Bakare, B.F. Effective biotreatment of acidic mine water and hospital wastewater using fluidized-bed reactors. J. Water Process Eng. 2020, 37, 101505. [CrossRef]

14. Dong, H.; Li, L.; Lu, Y.; Cheng, Y.; Wang, Y.; Ning, Q.; Wang, B.; Zhang, L.; Zeng, G. Integration of nanoscale zero-valent iron and functional anaerobic bacteria for groundwater remediation: A review. Environ. Int. 2019, 124, 265-277. [CrossRef]

15. Xiao, X.; Sheng, G.-P.; Mu, Y.; Yu, H.-Q. A modeling approach to describe ZVI-based anaerobic system. Water Res. 2013, 47, 6007-6013. [CrossRef]

16. Kumar, N.; Chaurand, P.; Rose, J.; Diels, L.; Bastiaens, L. Synergistic effects of sulfate reducing bacteria and zero valent iron on zinc removal and stability in aquifer sediment. Chem. Eng. J. 2015, 260, 83-89. [CrossRef]

17. Guo, J.; Kang, Y.; Feng, Y. Bioassessment of heavy metal toxicity and enhancement of heavy metal removal by sulfate-reducing bacteria in the presence of zero valent iron. J. Environ. Manag. 2017, 203, 278-285. [CrossRef]

18. Kolmert, Å.; Johnson, D.B. Remediation of acidic waste waters using immobilised, acidophilic sulfate-reducing bacteria. J. Chem. Technol. Biotechnol. Int. Res. Process. Environ. Clean Technol. 2011, 76, 836-843. [CrossRef]

19. Gallegos-Garcia, M.; Celis, L.B.; Rangel-Méndez, R.; Razo-Flores, E. Precipitation and recovery of metal sulfides from metal containing acidic wastewater in a sulfidogenic down-flow fluidized bed reactor. Biotechnol. Bioeng. 2009, 102, 91-99. [CrossRef] [PubMed]

20. Sahinkaya, E.; Dursun, N.; Ozkaya, B.; Kaksonen, A.H. Use of landfill leachate as a carbon source in a sulfidogenic fluidized-bed reactor for the treatment of synthetic acid mine drainage. Miner. Eng. 2013, 48, 56-60. [CrossRef]

21. Kaksonen, A.H.; Riekkola-Vanhanen, M.-L.; Puhakka, J.A. Optimization of metal sulphide precipitation in fluidized-bed treatment of acidic wastewater. Water Res. 2003, 37, 255-266. [CrossRef]

22. Makhathini, T.P.; Mulopo, J.; Bakare, B.F. Possibilities for Acid Mine Drainage Co-treatment with Other Waste Streams: A Review. Mine Water Environ. 2020, 39, 13-26. [CrossRef]

23. Laber, J.; Haberl, R.; Shrestha, R. Two-stage constructed welland for treating hospital wastewater in nepal. Water Sci. Technol. 1999, 40, 317-324. [CrossRef]

24. Sheoran, A.S.; Sheoran, V. Heavy metal removal mechanism of acid mine drainage in wetlands: A critical review. Miner. Eng. 2006, 19, 105-116. [CrossRef]

25. Allende, K.L.; McCarthy, D.T.; Fletcher, T.D. The influence of media type on removal of arsenic, iron and boron from acidic wastewater in horizontal flow wetland microcosms planted with Phragmites australis. Chem. Eng. J. 2014, 246, 217-228. [CrossRef]

26. Younger, P.L.; Henderson, R. Synergistic wetland treatment of sewage and mine water: Pollutant removal performance of the first full-scale system. Water Res. 2014, 55, 74-82. [CrossRef] [PubMed]

27. Ribas, D.; Cernik, M.; Benito, A.; Filip, J.; Marti, V. Activation process of air stable nanoscale zero-valent iron particles. Chem. Eng. J. 2017, 320, 290-299. [CrossRef]

28. Liu, Y.; Majetich, S.S.; Tilton, R.D.; Sholl, D.S.; Lowry, G.V. TCE dechlorination rates, pathways, and efficiency of nanoscale iron particles with different properties. Environ. Sci. Technol. 2005, 39, 1338-1345. [CrossRef]

29. APHA. Standard Methods for the Examination of Water and Wastewater, 22nd ed.; American Public Health Association: Washington, DC, USA, 2012.

30. Utgikar, V.P.; Harmon, S.M.; Chaudhary, N.; Tabak, H.H.; Govind, R.; Haines, J.R. Inhibition of sulfate-reducing bacteria by metal sulfide formation in bioremediation of acid mine drainage. Environ. Toxicol. 2002, 17, 40-48. [CrossRef] [PubMed]

31. Newbury, D.E.; Ritchie, N.W.M. Performing elemental microanalysis with high accuracy and high precision by scanning electron microscopy/silicon drift detector energy-dispersive X-ray spectrometry (SEM/SDD-EDS). J. Mater. Sci. 2015, 50, 493-518. [CrossRef] 
32. Janssen, A.J.H.; Ruitenberg, R.; Buisman, C.J.N. Industrial applications of new sulphur biotechnology. Water Sci. Technol. 2001, 44, 85-90. [CrossRef] [PubMed]

33. Velimirovic, M.; Simons, Q.; Bastiaens, L. Use of CAH-degrading bacteria as test-organisms for evaluating the impact of fine zerovalent iron particles on the anaerobic subsurface environment. Chemosphere 2015, 134, 338-345. [CrossRef]

34. Kirschling, T.L.; Gregory, K.B.; Minkley, J.; Edwin G, J.; Lowry, G.V.; Tilton, R.D. Impact of nanoscale zero valent iron on geochemistry and microbial populations in trichloroethylene contaminated aquifer materials. Environ. Sci. Technol. 2010, 44, 3474-3480. [CrossRef]

35. Venzlaff, H.; Enning, D.; Srinivasan, J.; Mayrhofer, K.J.J.; Hassel, A.W.; Widdel, F.; Stratmann, M. Accelerated cathodic reaction in microbial corrosion of iron due to direct electron uptake by sulfate-reducing bacteria. Corros. Sci. 2013, 66, 88-96. [CrossRef]

36. Liu, F.; Zhang, G.; Liu, S.; Fu, Z.; Chen, J.; Ma, C. Bioremoval of arsenic and antimony from wastewater by a mixed culture of sulfate-reducing bacteria using lactate and ethanol as carbon sources. Int. Biodeterior. Biodegrad. 2018, 126, 152-159. [CrossRef]

37. Zhang, Z.; Moon, H.S.; Myneni, S.C.B.; Jaffé, P.R. Effect of dissimilatory iron and sulfate reduction on arsenic dynamics in the wetland rhizosphere and its bioaccumulation in wetland plants (Scirpus actus). J. Hazard. Mater. 2017, 321, 382-389. [CrossRef] [PubMed]

38. Liu, H.; Zhang, B.; Yuan, H.; Cheng, Y.; Wang, S.; He, Z. Microbial reduction of vanadium (V) in groundwater: Interactions with coexisting common electron acceptors and analysis of microbial community. Environ. Pollut. 2017, 231, 1362-1369. [CrossRef]

39. Bai, H.; Kang, Y.; Quan, H.; Han, Y.; Feng, Y. Treatment of copper wastewater by sulfate reducing bacteria in the presence of zero valent iron. Int. J. Miner. Process. 2012, 112, 71-76. [CrossRef]

40. Ravikumar, K.V.G.; Shubham, A.; Shruthi, V.S.; Mrudula, P.; Natarajan, C.; Amitava, M. Nano-Bio sequential removal of hexavalent chromium using polymer-nZVI composite film and sulfate reducing bacteria under anaerobic condition. Environ. Technol. Innov. 2018, 9, 122-133. [CrossRef]

41. Mulopo, J. Pilot scale assessment of the continuous biological sulphate removal from coal acid mine effluent using grass cutting as carbon and energy sources. J. Water Process Eng. 2016, 11, 104-109. [CrossRef]

42. Song, H.; Yim, G.-J.; Ji, S.-W.; Nam, I.-H.; Neculita, C.M.; Lee, G. Performance of mixed organic substrates during treatment of acidic and moderate mine drainage in column bioreactors. J. Environ. Eng. 2012, 138, 1077-1084. [CrossRef]

43. Marquez-Reyes, J.M.; Lopez-Chuken, U.J.; Valdez-Gonzalez, A.; Luna-Olvera, H.A. Removal of chromium and lead by a sulfate-reducing consortium using peat moss as carbon source. Bioresour. Technol. 2013, 144, 128-134. [CrossRef]

44. Deng, D.; Weidhaas, J.L.; Lin, L.-S. Kinetics and microbial ecology of batch sulfidogenic bioreactors for co-treatment of municipal wastewater and acid mine drainage. J. Hazard. Mater. 2016, 305, 200-208. [CrossRef]

45. Neculita, C.-M.; Zagury, G.J.; Bussière, B. Passive treatment of acid mine drainage in bioreactors using sulfate-reducing bacteria. J. Environ. Qual. 2007, 36, 1-16. [CrossRef]

46. Sánchez-Andrea, I.; Sanz, J.L.; Bijmans, M.F.M.; Stams, A.J.M. Sulfate reduction at low pH to remediate acid mine drainage. J. Hazard. Mater. 2014, 269, 98-109. [CrossRef] [PubMed]

47. Li, S.; Wang, W.; Liang, F.; Zhang, W. Heavy metal removal using nanoscale zero-valent iron (nZVI): Theory and application. J. Hazard. Mater. 2017, 322, 163-171. [CrossRef] [PubMed]

48. Babel, S.; Kurniawan, T.A. Low-cost adsorbents for heavy metals uptake from contaminated water: A review. J. Hazard. Mater. 2003, 97, 219-243. [CrossRef]

49. Kieu, H.T.Q.; Muller, E.; Horn, H. Heavy metal removal in anaerobic semi-continuous stirred tank reactors by a consortium of sulfate-reducing bacteria. Water Res. 2011, 45, 3863-3870. [CrossRef]

50. Younger, P.L.; Banwart, S.A.; Hedin, R.S. Mine Water: Hydrology, Pollution, Remediation; Springer Science \& Business Media: Berlin, Germany, 2002.

51. Clyde, E.J.; Champagne, P.; Jamieson, H.E.; Gorman, C.; Sourial, J. The use of a passive treatment system for the mitigation of acid mine drainage at the Williams Brothers Mine (California): Pilot-scale study. J. Clean. Prod. 2016, 130, 116-125. [CrossRef]

52. Kiran, M.G.; Pakshirajan, K.; Das, G. An overview of sulfidogenic biological reactors for the simultaneous treatment of sulfate and heavy metal rich wastewater. Chem. Eng. Sci. 2017, 158, 606-620. [CrossRef]

53. Peer, R.A.M.; LaBar, J.A.; Winfrey, B.K.; Nairn, R.W.; Llanos Lopez, F.S.; Strosnider, W.H.J. Removal of less commonly addressed metals via passive cotreatment. J. Environ. Qual. 2015, 44, 704-710. [CrossRef] [PubMed]

54. Strosnider, W.H.J.; Nairn, R.W.; Peer, R.A.M.; Winfrey, B.K. Passive co-treatment of Zn-rich acid mine drainage and raw municipal wastewater. J. Geochemical Explor. 2013, 125, 110-116. [CrossRef]

55. Crane, R.A.; Scott, T.B. Nanoscale zero-valent iron: Future prospects for an emerging water treatment technology. J. Hazard. Mater. 2012, 211, 112-125. [CrossRef] [PubMed]

56. Madikizela, L.M.; Chimuka, L. Determination of ibuprofen, naproxen and diclofenac in aqueous samples using a multi-template molecularly imprinted polymer as selective adsorbent for solid-phase extraction. J. Phar. Biomed. Anal. 2016, 128, 210-215. [CrossRef] [PubMed]

57. Amday, R.; Chimuka, L.; Cukrowska, E. Determination of naproxen, ibuprofen and triclosan in wastewater using the polar organic chemical integrative sampler (POCIS): A laboratory calibration and field application. Water Sa 2014, 40, 407-414. [CrossRef]

58. Agunbiade, F.O.; Moodley, B. Pharmaceuticals as emerging organic contaminants in Umgeni River water system, KwaZulu-Natal, South Africa. Environ. Monit. Assess. 2014, 186, 7273-7291. [CrossRef] [PubMed] 
59. Dahane, S.; Gil Garcia, M.D.; Martinez Bueno, M.J.; Ucles Monreno, A.; Martinez Galera, M. Determination of drugs in river and wastewaters using solid-phase extraction by packed multi-walled carbon nanotubes and liquid chromatography-quadrupolelinear ion trap-mass spectrometry. J. Chromatogr. A. 2013, 1297, 17-28. [CrossRef]

60. Fichtel, K.; Mathes, F.; Könneke, M.; Cypionka, H.; Engelen, B. Isolation of sulfate-reducing bacteria from sediments above the deep-subseafloor aquifer. Front. Microbiol. 2012, 3, 65. [CrossRef]

61. Zacarías-Estrada, O.L.; Ballinas-Casarrubias, L.; Montero-Cabrera, M.E.; Loredo-Portales, R.; Orrantia-Borunda, E.; Luna-Velasco, A. Arsenic removal and activity of a sulfate reducing bacteria-enriched anaerobic sludge using zero valent iron as electron donor. J. Hazard. Mater. 2020, 384, 121392. [CrossRef]

62. Redmile-Gordon, M.; Chen, L. Zinc toxicity stimulates microbial production of extracellular polymers in a copiotrophic acid soil. Int. Biodeterior. Biodegrad. 2017, 119, 413-418. [CrossRef]

63. Labrenz, M.; Druschel, G.K.; Thomsen-Ebert, T.; Gilbert, B.; Welch, S.A.; Kemmer, K.M.; Logan, G.A.; Summons, R.E.; De Stasio, G.; Bond, P.L.; et al. Formation of sphalerite (ZnS) deposits in natural biofilms of sulfate-reducing bacteria. Science. 2000, 290, 1744-1747. [CrossRef]

64. Kumar, N.; Couture, R.-M.; Millot, R.; Battaglia-Brunet, F.; Rose, J. Microbial sulfate reduction enhances arsenic mobility downstream of zerovalent-iron-based permeable reactive barrier. Environ. Sci. Technol. 2016, 50, 7610-7617. [CrossRef] [PubMed]

65. Papirio, S.; Villa-Gomez, D.K.; Esposito, G.; Pirozzi, F.; Lens, P.N.L. Acid mine drainage treatment in fluidized-bed bioreactors by sulfate-reducing bacteria: A critical review. Crit. Rev. Environ. Sci. Technol. 2013, 43, 2545-2580. [CrossRef]

66. Johnson, D.B.; Hallberg, K.B. Acid mine drainage remediation options: A review. Sci. Total Environ. 2005, 338, 3-14. [CrossRef] [PubMed]

67. Hallberg, K.B.; Johnson, D.B. Biological manganese removal from acid mine drainage in constructed wetlands and prototype bioreactors. Sci. Total Environ. 2005, 338, 115-124. [CrossRef] [PubMed]

68. Mayes, W.M.; Batty, L.C.; Younger, P.L.; Jarvis, A.P.; Koiv, M.; Mander, U. Wetland treatment at extremes of pH: A review. Sci. Total Environ. 2009, 407, 3944-3957. [CrossRef] [PubMed]

69. Pearson, F.H.; Nesbitt, J.B. Acid mine drainage as a chemical coagulant for treatment of municipal wastewater. In Proceedings of the 5th Symposium Coal Mine Drainage Research, Lousville, KY, USA, 22-24 October 1974; pp. 181-191. 